\title{
Macronutrient Intake of 6-11 Months Old Infant on Mothers Obtaining Moringa Leaves and Iron Supplements
}

\author{
Sumiaty ${ }^{1,2}$, Abdullah Tahir ${ }^{3}$, Bahar Burhanuddin ${ }^{3}$, Jafar Nurhaedar ${ }^{3}$, Hadju Veni $^{3}$, Syafar Muhammad $^{3}$, \\ MasyitaMuis ${ }^{3}$, Sri Sumarmi ${ }^{4}$ \\ ${ }^{1}$ Doctoral Student in public Health, Universitas Hasanuddin, Indonesia, ${ }^{2}$ Lecturer of Faculty of Public Health, \\ Universitas Muslim, Indonesia, ${ }^{3}$ Lecturer of Faculty of Public Health, Universitas Hasanuddin, Indonesia, \\ ${ }^{4}$ Lecturer of Faculty of Public Health, Universitas Airlangga, Indonesia
}

\begin{abstract}
The study aimed to investigate the 6-11 months old infants' macronutrients intake on mothers obtaining moringa leaves and iron supplements.

Method:This experimental study complemented by kohort study was done in Jeneponto District in 2018 in which the samples were 6-11 months old infant. The research subject was 308 pregnant mothers categorized into 3 groups consisting of group which obtained moringa leaves powder (MLP, $n=103$ ), group which obtained moringa leaves extract (MLE, $n=94$ ) and group which obtained irons/folate (IFA, $n=111$ ). The data obtained were then analyzed using one way Anova and Kruskall Wallis to test the difference.

Results: The research found that different carbohydrate intake was found to be in the $10^{\text {th }}$ and $11^{\text {th }}$ month, while in the 7th, 8th and 9th month, there was no different carbohydrate intake between the three intervention groups $(p>0.005)$. Furthermore, based on the statistical test, different protein intake $(p<0.05)$ was also found in $10^{\text {th }}$ and $11^{\text {th }}$ month, while in $7^{\text {th }}, 8^{\text {th }}$ and $9^{\text {th }}$, there was no different protein intake between the three groups $(\rho>0.05)$. Meanwhile, regarding the fat intake, there was no difference in such between the three intervention groups in 7 to $10^{\text {th }}$ month $(\rho<0.05)$, while in the $11^{\text {th }}$ group, there was different fat intake $(\rho>0.05)$.

Conclusion: Different carbohydrate and protein intake was found in the 10th and 11th month, while different fat intake was found in the 11th month only between the three intervention groups. As they get older, there was increased macronutrient intake on MLP and MLE groups, however such thing does not happen in IFA group since there was decreased intake in the 11th month which did not meet the need. Thus, it is suggested that future researcher will give supplement intervention on 6-11 months old baby.
\end{abstract}

Keywords :Intake, Macronutrient, Baby, Moringa Leaves, Iron

\section{Introduction}

Complementary food is solid and semi-solid food containing nutrition and energy accompanying breast milk or formula milk to be given to infant which usually introduced to the baby at the range of 4-6 months old ${ }^{1}$. Optimal complementary food is one of the components to improve infants' nutritional status and health in their first 1000 days starting during the pregnancy until the second year of the infant ${ }^{2-4}$.Malnutrition causes the mortality of 3.1 million children annually ${ }^{5}$, thus baby and infant food directly determines the nutritional status of childre.

The high malnutrition during childhood is caused by inadequate food intake. There was only $55 \%$ of less than 6 months old infant who were breastfeed exclusively and only $7 \%$ of $6-8$ months old infant who were feed as recommended by WHO. This indicates that there was high stunting prevalence at the age of 3 months old. High quality diet starting from the age of 6 months should be done in order to decrease the stunting rate at the second year ${ }^{6}$. 
Decreased prevalence occurred during solid, semi-solid and soft food feeding between the educated mothers on 6-8 months old infant $(67 \%$ in 2003 into $57 \%$ in 2013); minimal food diversity (33\% in 2003 into $24 \%$ in 2013$)$ and minimum acceptable diet (13\% in 2003 into $8 \%$ in 2013) 7 .

Infants at the age of 6-12 months old have lower decreased stunting rate than children at the age of 3647 months old ${ }^{8}$. A research project that was performed in India found that stunting was mostly found in 36-47 months old children than 48-59 months old children. This is due to the bad weaning and complementary feeding which contribute to the children's energy and protein intake inadequately.

High protein complementary food is related linearly to the growth and body weight of the infants who are kept breastfeed but does not add the adiposity ${ }^{1}$. Circadian distribution of energy consumption can affect the adipose tissue and body weight of 12 months old infant. Bigger adipose tissue increases overweight risk on children who were feed at night more than during the day $^{9,10}$

Malnutrition on 6-8 months old infant is indicated by the lack of iron, zinc, and niacin, while malnutrition on 9-11 months old infant in indicated by inadequate complementary food so that it is suggested to add meat, fish, chicken and egg (MFPE) on the infants' complementary food ${ }^{11}$. The objective of this research is to investigate the difference in 6-11 months old infants' macronutrient intake on mothers obtaining moringa leaves and irons supplements.

\section{Materials and Method}

Experimental research continued by cohort study was done by choosing 6-11 months old infants as the sample. This research was done in Jeneponto District in 2018 collecting 308 pregnant mothers as the research subject. The subjects were then grouped into three consisting of mothers who obtained moringa leaves powder (MLP, $n=103$ ), mothers who obtained moringa leaves extract (MLE, $n=94$ ) and mothers who obtained irons/folate (IFA, $\mathrm{n}=111$ ). The inclusion criteria to choose the pregnant mothers were those who were at the second trimester and one month after giving birth, have given birth for $\leq 3$ times, have single fetus, willing to consume capsule for 4 months and did not consume other multivitamin and mineral during the research. The research variable was breastfeeding on 6-11 months old infant. The mothers and children characteristics were found using questionnaire and analyzed using one wayAnova and Kruskall Walli. This research has obtained approval from the Ethical Committee of the Faculty of Medicine of Universitas Hasanuddin number 1071909130.

\section{Results}

Table 1. Distribution Based on Parents' Characteristics

\begin{tabular}{|c|c|c|c|c|c|c|c|c|c|}
\hline \multirow{2}{*}{ Variable } & \multicolumn{2}{|c|}{$\begin{array}{l}\text { MLP } \\
(\mathrm{n}=103)\end{array}$} & \multicolumn{2}{|c|}{$\begin{array}{l}\text { MLE } \\
(\mathrm{n}=94)\end{array}$} & \multicolumn{2}{|c|}{$\begin{array}{l}\text { IFA } \\
(n=111)\end{array}$} & \multicolumn{2}{|c|}{$\begin{array}{l}\text { TOTAL } \\
(\mathrm{N}=\mathbf{3 0 8})\end{array}$} & \multirow[t]{2}{*}{$\rho$ value } \\
\hline & $\mathrm{n}$ & $\%$ & $\mathrm{n}$ & $\%$ & $\mathrm{n}$ & $\%$ & $\mathbf{n}$ & $\%$ & \\
\hline $\begin{array}{l}\text { Mothers' Age } \\
<26 \text { years old } \\
>=26 \text { years old }\end{array}$ & $\begin{array}{l}36 \\
67\end{array}$ & $\begin{array}{l}35.0 \\
65.0\end{array}$ & $\begin{array}{l}33 \\
61\end{array}$ & $\begin{array}{l}35.1 \\
64.9\end{array}$ & $\begin{array}{l}39 \\
72\end{array}$ & $\begin{array}{l}35.1 \\
64.9\end{array}$ & $\begin{array}{l}108 \\
200\end{array}$ & $\begin{array}{l}35.1 \\
64.9\end{array}$ & 1.000 \\
\hline $\begin{array}{l}\text { Mothers' Education } \\
\text { Low ( }<12 \text { years) } \\
\text { High ( }>=12 \text { years })\end{array}$ & $\begin{array}{l}70 \\
33\end{array}$ & $\begin{array}{l}68.0 \\
32.0\end{array}$ & $\begin{array}{l}64 \\
30\end{array}$ & $\begin{array}{l}68.1 \\
31.9\end{array}$ & $\begin{array}{l}75 \\
36\end{array}$ & $\begin{array}{l}67.6 \\
32.4\end{array}$ & $\begin{array}{l}209 \\
99\end{array}$ & $\begin{array}{l}67.9 \\
32.1\end{array}$ & 0.996 \\
\hline
\end{tabular}


Cont.. Table 1. Distribution Based on Parents' Characteristics

\begin{tabular}{|l|l|l|l|l|l|l|l|l|l|}
\hline Mothers' Occupation & & & & & & & & & \\
Do not work & 81 & 78.6 & 80 & 85.1 & 89 & 85.1 & 250 & 81.2 & 0.483 \\
Work & 2 & 21.4 & 14 & 14.9 & 22 & 14.9 & 58 & 18.5 & \\
\hline Fathers' Education & & & & & & & & & \\
Low (<12 years) & 67 & 65.0 & 64 & 68.1 & 70 & 63.1 & 201 & 65.3 & 0.752 \\
High (>=12 years) & 36 & 35.0 & 30 & 31.9 & 41 & 36.9 & 107 & 34.7 & \\
\hline $\begin{array}{l}\text { Fathers' Occupation } \\
\text { Farmer/fisher }\end{array}$ & 44 & 42.7 & 40 & 42.6 & 48 & 43.2 & 132 & 42.9 & \\
$\begin{array}{l}\text { Civil Servant/Private } \\
\text { Employees }\end{array}$ & 11 & 10.7 & 16 & 17.0 & 19 & 17.1 & 46 & 14.9 & \\
$\begin{array}{l}\text { Driver/Daily Laborer } \\
\text { Entrepreneur }\end{array}$ & 32 & 31.1 & 21 & 22.3 & 23 & $20 / 7$ & 76 & 24.7 & 0.600 \\
Others & 12 & 11.7 & 14 & 14.9 & 19 & 17.1 & 45 & 14.6 & \\
\hline Income & 4 & 3.9 & 3 & 3.2 & 2 & 1.8 & 9 & 2.9 & \\
$<2$ million & 79 & 76.7 & 64 & 68.1 & 78 & 70.3 & 221 & 71.8 & 0.370 \\
$\geq 2$ million & 24 & 23.3 & 30 & 31.9 & 33 & 29.7 & 87 & 28.2 & \\
\hline
\end{tabular}

Fathers, most of them have low education as well by 201 fathers (65.3\%), mostly worked as farmer/fisher by 132 fathers $(42.9 \%)$, and most of them have income of less than 2 million by 221 fathers $(71.8 \%)$

Table 2. Distribution Based on the Infants' Characteristics

\begin{tabular}{|c|c|c|c|c|c|c|c|c|c|}
\hline \multirow{2}{*}{ Variable } & \multicolumn{2}{|c|}{$\begin{array}{l}\text { MLP } \\
(\mathrm{n}=103)\end{array}$} & \multicolumn{2}{|c|}{$\begin{array}{l}\text { MLE } \\
(n=94)\end{array}$} & \multicolumn{2}{|c|}{$\begin{array}{l}\text { IFA } \\
(n=111)\end{array}$} & \multicolumn{2}{|c|}{$\begin{array}{l}\text { TOTAL } \\
(\mathbf{N}=\mathbf{3 0 8})\end{array}$} & \multirow[t]{2}{*}{ p-value } \\
\hline & $\mathbf{n}$ & $\%$ & $\mathbf{n}$ & $\%$ & $\mathbf{N}$ & $\%$ & $\mathbf{n}$ & $\%$ & \\
\hline $\begin{array}{l}\text { Gender } \\
\text { Male } \\
\text { Female }\end{array}$ & $\begin{array}{l}60 \\
43\end{array}$ & $\begin{array}{l}58.3 \\
41.7\end{array}$ & $\begin{array}{l}47 \\
47\end{array}$ & $\begin{array}{l}50.0 \\
50.0\end{array}$ & $\begin{array}{l}60 \\
51\end{array}$ & $\begin{array}{l}54.1 \\
45.9\end{array}$ & $\begin{array}{l}167 \\
141\end{array}$ & $\begin{array}{l}54.2 \\
45.8\end{array}$ & 0.509 \\
\hline $\begin{array}{l}\text { Birth Weight } \\
\text { Low } \\
\text { Normal }\end{array}$ & $\begin{array}{l}1 \\
102\end{array}$ & $\begin{array}{l}1.0 \\
99.0\end{array}$ & $\begin{array}{l}3 \\
91\end{array}$ & $\begin{array}{l}3.2 \\
96.8\end{array}$ & $\begin{array}{l}9 \\
102\end{array}$ & $\begin{array}{l}8.1 \\
91.9\end{array}$ & $\begin{array}{l}13 \\
295\end{array}$ & $\begin{array}{l}4.2 \\
95.8\end{array}$ & 0.029 \\
\hline $\begin{array}{l}\text { Birth Length } \\
>=48 \mathrm{~cm} \\
<48 \mathrm{~cm}\end{array}$ & $\begin{array}{l}94 \\
9\end{array}$ & $\begin{array}{l}91.3 \\
8.7\end{array}$ & $\begin{array}{l}81 \\
13\end{array}$ & $\begin{array}{l}86.2 \\
13.8\end{array}$ & $\begin{array}{l}89 \\
22\end{array}$ & $\begin{array}{l}80.2 \\
19.8\end{array}$ & $\begin{array}{l}264 \\
44\end{array}$ & $\begin{array}{l}85.7 \\
14.3\end{array}$ & 0.068 \\
\hline $\begin{array}{l}\text { Breastfeed } \\
\text { Yes } \\
\text { No }\end{array}$ & $\begin{array}{l}82 \\
21\end{array}$ & $\begin{array}{l}79.6 \\
20.4\end{array}$ & $\begin{array}{l}77 \\
17\end{array}$ & $\begin{array}{l}81.9 \\
18.1\end{array}$ & $\begin{array}{l}91 \\
20\end{array}$ & $\begin{array}{l}82.0 \\
18.0\end{array}$ & $\begin{array}{l}250 \\
58\end{array}$ & $\begin{array}{l}81.2 \\
18.8\end{array}$ & 0.884 \\
\hline $\begin{array}{l}\text { Complementary Food } \\
<6 \text { months } \\
>=6 \text { months }\end{array}$ & $\begin{array}{l}24 \\
79\end{array}$ & $\begin{array}{l}23.3 \\
76.7\end{array}$ & $\begin{array}{l}27 \\
67\end{array}$ & $\begin{array}{l}28.7 \\
71.3\end{array}$ & $\begin{array}{l}24 \\
87\end{array}$ & $\begin{array}{l}21.6 \\
78.4\end{array}$ & $\begin{array}{l}76 \\
232\end{array}$ & $\begin{array}{l}24.7 \\
75.3\end{array}$ & 0.498 \\
\hline $\begin{array}{l}\text { Parity } \\
1 \\
>1\end{array}$ & $\begin{array}{l}28 \\
75\end{array}$ & $\begin{array}{l}27.2 \\
72.8\end{array}$ & $\begin{array}{l}28 \\
66\end{array}$ & $\begin{array}{l}29.8 \\
70.2\end{array}$ & $\begin{array}{l}40 \\
71\end{array}$ & $\begin{array}{l}36.0 \\
64.0\end{array}$ & $\begin{array}{l}96 \\
212\end{array}$ & $\begin{array}{l}31.2 \\
68.8\end{array}$ & 0.355 \\
\hline
\end{tabular}


Table 2 above gives information that most of the infants were male by 167 infants (54.2\%), their birth weight was mostly 295 infants( $95.8 \%$ ), while the birth length was mostly $\geq 48 \mathrm{~cm}$ by 264 infants $(85.7 \%)$. Most of them were still breastfeed by 250 infants $(81.2 \%)$, given complementary food during $\geq 6$ months old by $232(75.3 \%)$, and most parity was $>1$ which is by 212 infants $(68.8 \%)$.

\section{Macronutrient Intake}

Table3. Mean Carbohydrate Intake for Infant on the Three Intervention Groups

\begin{tabular}{|l|l|l|l|l|}
\hline \multirow{2}{*}{ Carbohydrate (gram) } & \multicolumn{2}{|l|}{ Mean Intake } & \multirow{2}{*}{ -value } \\
\cline { 2 - 5 } & MLP & MLE & IFA & \\
\hline 7th month & $28.519 \pm 27.83$ & $28.17 \pm 21.68$ & $25.87 \pm 21.91$ & $0.600 \mathrm{~b}$ \\
\hline 8th month & $30.27 \pm 23.09$ & $38.96 \pm 24.48$ & $32.79 \pm 22.54$ & $0.113 \mathrm{a}$ \\
\hline 9th month & $38.90 \pm 28.99$ & $45.32 \pm 24.27$ & $40.63 \pm 26.91$ & $0.434 \mathrm{a}$ \\
\hline 10 th month & $35.31 \pm 22.27$ & $49.12 \pm 20.37$ & $45.28 \pm 25.01$ & $0.002 \mathrm{~b}$ \\
\hline 11 th month & $40.65 \pm 25.21$ & $57.02 \pm 27.00$ & $43.56 \pm 24.48$ & $0.001 \mathrm{~b}$ \\
\hline
\end{tabular}

It shows that between the three intervention groups, there was no different carbohydrate intake on the $7^{\text {th }}, 8^{\text {th }}$, and $9^{\text {th }}$ month $(\rho>0.05)$, while on the $10^{\text {th }}$ and $11^{\text {th }}$ month, there was different carbohydrate intake $(\rho<0.05)$. On MLP and MLE groups, as the infants got older, the carbohydrate intake also increased but not IFA group since there was decreased intake on the $11^{\text {th }}$ month.

Table4. Mean Protein Intake for Infant on the Three Intervention Groups

\begin{tabular}{|c|c|c|c|c|}
\hline \multirow{2}{*}{ Protein (gram) } & \multicolumn{3}{|c|}{ Mean Intake } & \multirow{2}{*}{$\rho$-value } \\
\hline & MLP & MLE & IFA & \\
\hline 7th month & $5.38 \pm 5.90$ & $5.37 \pm 4.41$ & $4.80 \pm 3.85$ & $0.354 \mathrm{~b}$ \\
\hline 8th month & $5.34 \pm 3.44$ & $6.63 \pm 5.00$ & $6.27 \pm 4.20$ & $0.387 \mathrm{~b}$ \\
\hline 9th month & $6.94 \pm 4.99$ & $7.32 \pm 4.13$ & $6.83 \pm 3.91$ & $0.621 \mathrm{~b}$ \\
\hline 10th month & $7.94 \pm 5.65$ & $9.81 \pm 4.88$ & $9.39 \pm 5.29$ & $0.026 \mathrm{~b}$ \\
\hline 11th month & $7.61 \pm 5.03$ & $12.61 \pm 7.74$ & $8.37 \pm 5.87$ & $0.000 \mathrm{a}$ \\
\hline
\end{tabular}

Table 4 presents the result of statistical result showing that among the three groups, there was no different protein intake on the $7^{\text {th }}, 8^{\text {th }}$, and $9^{\text {th }}$ month $(\rho>0.05)$, while on the $10^{\text {th }}$ and $11^{\text {th }}$ month, there was different protein intake $(\rho<0.05)$. On MLP and MLE groups, as the infants got older, the protein intake also increased but not on the IFA group since there was decreased intake on the $11^{\text {th }}$ month. 
Table5. Mean Fat Intake for Infant on the Three Intervention Groups

\begin{tabular}{|c|c|c|c|c|}
\hline \multirow{2}{*}{ Fat (gram) } & \multicolumn{3}{|c|}{ Mean Intake } & \multirow{2}{*}{$\rho$-value } \\
\hline & MLP & MLE & IFA & \\
\hline $7^{\text {th }}$ month & $4.20 \pm 7.63$ & $4.31 \pm 5.62$ & $3.48 \pm 4.22$ & $0.491^{b}$ \\
\hline $8^{\text {th }}$ month & $4.37 \pm 6.53$ & $5.04 \pm 6.20$ & $4.62 \pm 4.64$ & $0.401^{b}$ \\
\hline $9^{\text {th }}$ month & $5.39 \pm 7.27$ & $5.38 \pm 6.12$ & $4.80 \pm 5.35$ & $0.917^{\mathrm{b}}$ \\
\hline $10^{\text {th }}$ month & $6.29 \pm 6.27$ & $7.34 \pm 5.59$ & $6.88 \pm 6.19$ & $0.298^{b}$ \\
\hline $11^{\text {th }}$ month & $5.55 \pm 4.87$ & $8.84 \pm 6.66$ & $6.23 \pm 6.36$ & $0.004^{\mathrm{a}}$ \\
\hline
\end{tabular}

Table5 shows that fat intake on the 7th, 8th, $9^{\text {th }}$ and 10th month were not different among the three intervention groups $(\rho<0.05)$, while on the $11^{\text {th }}$ month, there was different fat intake between the groups $(\rho>0.05)$. On MLP and MLE groups, as the infants got older, the fat intake also increased but not on the IFA group since there was decreased intake on the $11^{\text {th }}$ month.

\section{Discussion}

Among the three groups studied, the carbohydrate intake by the infants were not different significantly on the $7^{\text {th }}, 8^{\text {th }}$ and $9^{\text {th }}$ month, but it showed significant difference on the $10^{\text {th }}$ and $11^{\text {th }}$ month. On MLP and MLE groups, as the infants got older, the carbohydrate intake also increased but not on the IFA group since there was decreased intake on the $11^{\text {th }}$ month, and the amount of intake on MLE group was more than the other two intervention groups. However, the amount has not reached the standard of 7-11 months old infants' need which is $82 \mathrm{~g} / \mathrm{h}$ without breast milk. Meanwhile, if it was complementing breast milk of $7.0 \mathrm{~g} / \mathrm{h}$ added by the highest content in the research which is $57.02 \mathrm{~g} / \mathrm{h}$.

Protein is an important nutrient composition of complementary food. It is the main source of amino acid. Adequate protein food intake is very important in protecting the cell function and integrity to ensure normal health and growth. Furthermore, the lack of protein and low energy intake can cause malnutrition of proteinenergy (PE) which is the most common malnutrition form in the world ${ }^{12}$

Regarding the protein intake, there was no significant difference found either on the $7^{\text {th }}, 8^{\text {th }}$ and $9^{\text {th }}$ month, instead it was found on the $10^{\text {th }}$ and $11^{\text {th }}$ month. Infants' protein need increases as they get older proven by the research result that on MLP and MLE groups but not on IFA group due to decreased intake on the $11^{\text {th }}$ month.

The amount of protein (gram/day) needed to adequate the infants' nutrition need both from the breast milk and complementary food is $9.1 \mathrm{~g}$ for 6-8 months old infant, $9.6 \mathrm{~g}$ for $9-11$ months old ${ }^{13}$ and $18 \mathrm{~g} / \mathrm{h}$ according to Regulation of Ministry of Health. Breast milk provides significant protein need for the infant. If the average breast milk assumed, then the amount of protein needed from the complementary food is $1.9 \mathrm{~g}$ /day on 6-8 months old (21\%), $4.0 \mathrm{~g} /$ day on 9-11 months old (42\%), and $6.2 \mathrm{~g} /$ day $(57 \%)$ on 12-23 months old ${ }^{14}$. Based on this research, the amount of protein intake consumed by the infants other than the breast milk protein on the three intervention groups at the age of 7-8 and 9-11 months old was $\geq 4.8 \mathrm{~g} /$ dayand $\geq 6.8 \mathrm{~g} /$ day which means that the protein intake was above the standard suggested.

Fat provides essential fat acid, facilitates the absorbance of vitamin dissolved in fat as well as improves energy solid food pattern and sensory quality thus it is important for the infant and children diet. Breast milk is usually has more fat than the complementary food. Therefore, total fat intake usually decreases as the older of breast milk contribution on the decrease of total food 
energy.

Among the three intervention groups, there was no significant difference found in fat intake during the $7^{\text {th }}$, $8^{\text {th }}, 9^{\text {th }}$ and $10^{\text {th }}$ month. However, there was significant difference on the $11^{\text {th }}$ month. On MLP and MLE groups, the amount of infants' fat intake increases as the infants got older, but it did not happen on IFA group and the amount of intake on MLE group is more than the other two intervention groups. However, the amount is way below the standard and such thing does not affect some infants due to the breastfeeding.

Even though there is debate regarding the optimal amount of fat in infants and children food, the range of $30-45 \%$ of total energy is suggested ${ }^{15}$. The percentage of energy from the fat in complementary food needed to reach $30-45 \%$ energy from fat in total diet depends on the breast milk intake and fat level of breast (15). Infants in developing countries usually consume breast milk with normal fat concentration (38 g/L). When developing the diet guideline to provide adequate fat for complementary food, the potential effect of the fat added needs to be considered (such as oil added by porridge) on the nutrition of the food. For example, the addition of one teaspoon of vegetable oil to $100 \mathrm{~g}$ typical corn peppers used in West Africa can increase the energy density from 0.28 to $0.73 \mathrm{kkal} / \mathrm{g}$, but it will decrease the protein density from $8.9 \%$ to $3.3 \%$ from the energy and irons density from 0.5 to $0.2 \mathrm{mg} / 100 \mathrm{kkal}$.

\section{Conclusion}

Different carbohydrate and protein intake was found in the $10^{\text {th }}$ and $11^{\text {th }}$ month, while different fat intake was found in the $11^{\text {th }}$ month only between the three intervention groups. On MLP and MLE groups, the older they get, the more increase the macronutrient intake. However, it does not happen on IFA group because there was decreased intake on the $11^{\text {th }}$ month but it did not adequately fulfill the need so the future researcher needs to give supplement intervention on 6-11 months old infants.

Source of Funding: This study was sponsored by Ministry of research and higher education

Ethical Clearance: Obtained from Hasanuddin University ethical committee
Conflict of Interest : None

\section{References}

1. Tang M, Krebs NF. High protein intake from meat as complementary food increases growth but not adiposity in breastfed infants: A randomized trial. Am J Clin Nutr. 2014;100(5):1322-8.

2. Bhutta ZA, Das JK, Rizvi A, Gaffey MF, Walker $\mathrm{N}$, Horton S, et al. Evidence-based interventions for improvement of maternal and child nutrition: What can be done and at what cost? Lancet. 2013;382(9890):452-77.

3. Lutter CK, Daelmans BMEG, de Onis M, Kothari MT, Ruel MT, Arimond M, et al. Undernutrition, Poor Feeding Practices, and Low Coverage of Key Nutrition Interventions. Pediatrics. 2011;128(6):e1418-27.

4. Dewey KG, Brown KH. Update on technical issues concerning complementary feeding of young children in developing countries and implications for intervention programs. Food Nutr Bull. 2003;24(1):5-28.

5. Black RE, Victora CG, Walker SP, Bhutta ZA, Christian P, De Onis M, et al. Maternal and child undernutrition and overweight in lowincome and middle-income countries. Lancet. 2013;382(9890):427-51.

6. Owais A, Schwartz B, Kleinbaum DG, Suchdev PS, Faruque ASG, Das SK, et al. Minimum acceptable diet at 9 months but not exclusive breastfeeding at 3 months or timely complementary feeding initiation is predictive of infant growth in rural Bangladesh. PLoS One. 2016;11(10):1-10.

7. Ogbo FA, Page A, Idoko J, Claudio F, Agho KE. Trends in complementary feeding indicators in Nigeria, 2003-2013. BMJ Open. 2015;5(10):e008467.

8. Olack B, Burke H, Cosmas L, Bamrah S, Dooling K, Feikin DR, et al. Nutritional status of under-five children living in an informal urban settlement in Nairobi, Kenya. J Heal Popul Nutr. 2011;29(4):35763.

9. Cheng TS, Loy SL, Toh JY, Cheung YB, Chan JKY, Godfrey KM, et al. Predominantly nighttime feeding and weight outcomes in infants. Am J Clin Nutr. 2016;104(2):380-8.

10. Yuan WL, Nicklaus S, Lioret S, Lange C, Forhan A, Heude B, et al. Early factors related to carbohydrate 
and fat intake at 8 and 12 months: results from the EDEN mother-child cohort. Eur J Clin Nutr. 2017;71(2):219-26.

11. Fahmida U, Santika O, Kolopaking R, Ferguson E. Complementary feeding recommendations based on locally available foods in Indonesia. Food Nutr Bull. 2014;35(4):S174-9.

12. Intakes DR. Dietary Reference Intakes ( DRI ).

13. WHO PAHO. Guiding Principles for Complementary Feedin $\mathrm{g}$ of The Breastfed Child. 2001;
14. Dewey KG. Nutrition, Growth , And Complementary Feeding Of The Breastfed Infant. 2001;48(1).

15. Dewey KG, Brown KH. Update on technical issues concerning complementary feeding of young children in developing countries and implications for intervention programs. 2003;24(1):5-28. 